\title{
Dietha Koster (Münster)/Hanneke Loerts (Groningen) Food for psycholinguistic thought on gender in Dutch and German: a literature review on L1 and L2 production and processing
}

\begin{abstract}
The aim of this paper is to explore how variation in the expression of gender has been and can be exploited to study gender perception in speakers of Dutch and German. We provide an up-to-date literature review on descriptive and psycholinguistic research on gender for these languages, considering empirical studies on both native (L1) and second language (L2) acquisition. This paper contributes to placing existing literature on gender in Dutch and German in a comparative mode and to offering a concrete rationale (e.g., three lines of enquiry) to move the psycholinguistic study of language, cognition and gender forward.

Zusammenfassung: Das Ziel dieses Papers ist es herauszufinden, wie sich Unterschiede von Gender im Ausdruck von Sprache erfassen lassen und wie die Ergebnisse genutzt werden können, um die Perzeption von Gender bei niederländischen und deutschen Sprechern zu untersuchen. Vorgestellt wird eine aktuelle Übersicht der deskriptiven und psycholinguistischen Forschungsliteratur zum Thema Gender in diesen beiden Sprachen, wobei der Fokus auf empirischen Studien nach Erst- (L1) und Zweitspracherwerb (L2) liegt. Dieser Beitrag ermöglicht somit den Vergleich der vorhandenen deutschen und niederländischen Genderliteratur und liefert im Ergebnis konkrete Ansätze (z.B. drei Forschungsgebiete), um die psycholinguistische Forschung von Sprache, Kognition und Gender weiter voranzubringen.
\end{abstract}

\section{Introduction}

An increasing number of studies investigates effects of gender language(s) on cognition (Garnham et al. 2016). Speakers of all languages are familiar with semantic gender, as in the words father and daughter, where the referent's biological sex is encoded in the word's meaning. ${ }^{1}$ The WALS sample suggests that 127 languages (43.6\%) also have a lexical gender system that divides all

1 We thank two anonymous reviewers for constructive criticism and comments.

D Open Access. (C) 2020 Koster/Loerts, published by De Gruyter. (c) Br-NC.ND This work is licensed under the Creative Commons Attribution-NonCommercial-NoDerivatives 4.0 License. https://doi.org/10.1515/9783110668476-012 
nouns in the language into categories such as feminine, masculine, and neuter (Dryer/Haspelmath 2013 (eds.)). ${ }^{2}$ These systems are often referred to as grammatical gender systems since the genders of nouns are reflected in other words related to these nouns (henceforth, we employ the term lexical gender). Anyone who has ever learned a foreign language with lexical gender will be familiar with the seemingly arbitrary division of (especially inanimate) nouns across these categories. For example, why is the word for sun feminine in German (die Sonne) and the word for moon masculine (der Mond)? And why do the French refer to that same sun as masculine (le soleil), but to the moon as feminine (la lune)? Interestingly, even for animate nouns, there is not always an overlap between semantic and lexical gender. A telling example is the two-way Dutch gender system that used to consist of masculine, feminine, and neuter nouns, but now only contains common de-words and neuter het-words (De Vogelaer 2012). There is thus no longer a lexical gender marker distinguishing the woman (de vrouw) from the man (de man). While such a distinction is still present in the three-way German gender system (die Frau [the woman] and der Mann [the man]), it is not always consistent with semantic gender. Men, for example, mostly belong to the masculine gender category (e.g., der Herr [sir]), but women - both in German and in Dutch - are also assigned to the neuter lexical gender category: das Mädchen; het meisje [the girl] and das Weib; het wijf [the woman].

Psycholinguistic research thus far suggests that both semantic and lexical gender have profound effects on how we perceive gender of animate and inanimate entities. For example, Boroditsky/Schmidt/Philipps (2003) found that lexical gender affects whether German and Spanish speakers perceive objects as masculine or feminine, even without producing language. Yet, due to limitations and failures to replicate (Everett 2013), it is unclear whether such effects hold across languages and contexts. Semantic gender marked for professional titles affects whether women are perceived as relevant candidates for leadership positions. Horvath/Szcesny (2016) for example, found that a hiring committee perceived female applicants as less fit to fill high-status leadership positions, when a male noun was used generically with or without (m/f) (e.g., Geschäftsführer ( $m / w)$ [CEO]) in German job advertisements (also see Vermeulen 2018). Women and men were perceived as equally fit when pair forms were

2 Most languages contain some nouns that can be placed into more than one category, such as German die/das Cola [the coke] and die/das Email [the email], and Dutch de/het marsepein [the marzipan] and de/het matras [the mattress]. In most of these cases the preference for one gender or the other seems to be determined by geography or style (also see Semplicini 2012). 
employed (e.g., Geschäftsführerin/Geschäftsführer [CEO-fem/male]). On the other hand, it has been shown that the use of German and Italian female professional titles decreases the value that participants ascribe to typically feminine professions (Horvath et al. 2015). Whether and how feminizing or neutralizing practices benefits gender fairness in different languages thus remains to be determined. Though German semantic gender has been investigated quite extensively from a psycholinguistic perspective, research into Dutch gender, in comparison, is less exhaustive. Many studies have focused on gender perception in adult, native (L1) speakers of a language, whereas only in more recent years, research on gender perception in younger and bilingual speakers has started to increase.

The aim of the present paper is to provide an up-to-date literature review on descriptive and psycholinguistic gender research in Dutch and German. The overarching goal is moving the study of perception of gendered language in both L1 and second language (L2) speakers forward (as argued for in Pavlenko 2014). We first focus on descriptive linguistic studies to identify similarities and differences in gender marking in grammar and for personal nouns. An important reason for focusing on personal nouns is that they constitute a basic and culturally significant lexical field in almost any language (Hellinger/Bußmann 2001). Second, we focus on psycholinguistic work that has investigated the acquisition, processing and perception of gender in Dutch and/or German. We consider both studies that take offline measures (e.g., questionnaires, categorization tasks etcetera) as well as online measures (e.g., eye tracking and eventrelated brain potentials (ERPs)). We consider both research on gender perception with child and adult L1 speakers as well as studies with L2 learners of Dutch and/or German. Studies into child L1 acquisition are of interest, as they show at what ages gender categories are formed and used during production and perception. This is both of theoretical as well as descriptive value, as observed norms may be employed in educational and clinical practice. In line with Pavlenko (2014) we argue that L2 learners too constitute a favorable ground for testing psycholinguistic theory: "two languages in one mind" provide a unique test case for questions into, for example, changes in perception when shifting between languages. Perceptive shifts have been well-documented for, for example, motion perception across languages (Athanasopoulos et al. 2015), but for gender perception, bi- or multilingual studies have started to emerge only within the last decades. 


\section{The expression of gender in Dutch and German}

Hellinger/Bußmann (eds.) (2001, 2002, 2003) and Hellinger/Motschenbacher (eds.) (2015) have provided a systematic description of similarities and differences in the expression of gender for over 40 languages. Drawing on Hellinger/ Bußmann (2001: 7), we define semantic gender as the specification of nouns "as carrying the semantic property [female] or [male]", which may relate to the referent's sex. Lexical gender, on the other hand, can be defined as a noun classification system, which "is reflected beyond the nouns themselves in modification required of 'associated words"' (Corbett 1991: 4). The latter part of this definition refers to grammatical gender, the agreement system which, as argued by Corbett, is the most defining attribute of gender. Though Dutch and German are both West Germanic languages, we find differences in the expression of semantic and lexical gender. Before discussing the semantic gender systems, the next section reviews lexical gender in the two languages. The theoretical distinction between semantic and lexical gender will not always be upheld in the following due to studies that incorporate both concepts. We use the term grammatical gender in case authors have employed this term themselves.

\subsection{Lexical gender in Dutch and German}

All nouns in Dutch and German, as in any language with a lexical gender system, belong to one of the gender categories of the language. There is sometimes a correspondence between the "feminine" and the "masculine" gender class and the specification of a noun as female-specific or male-specific (the German lexically masculine noun Mann [man] is preceded by the masculine article der [the]). For inanimate nouns, however, the gender category of a word often seems completely arbitrary and can differ between languages, showing that lexical gender differs from biological gender. Gender comes from the Latin word la genus, which means "sort" or "class". Languages with lexical gender are thus languages that have a small number of gender classes that nouns are assigned to, typically two or three: masculine, feminine and neuter. In addition to the assignment system, i.e., the classification of nouns belonging to a gender category, there is an agreement system. In languages such as German and Dutch, nouns do not necessarily carry markers of gender class membership, but there is obligatory agreement with other word classes, such as articles, adjectives, pronouns, verbs, numerals or prepositions. 


\subsubsection{Lexical gender in Dutch}

Dutch currently employs a two-way gender system but used to have a three-way lexical gender system with masculine, feminine, and neuter nouns. ${ }^{3}$ The original masculine and feminine genders have evolved and collapsed into one common gender category and, consequently, this category is relatively large making up at least 75\% of all nouns (van Berkum 1996: 23). Current Netherlandic Dutch thus employs a single definite determiner (e.g., de [the]) with nouns, that does not mark masculine or feminine gender (Gerritsen 2002; De Vogelaer 2012). Traces of masculine and feminine gender are still visible in references using personal (hij/hem [he/him] and zij/haar [she/her]) and possessive pronouns (zijn [his] and haar [her] (also for inanimates, see Audring 2006)). Furthermore, many substandard Belgian Dutch varieties still mark masculine, feminine and neuter gender. There is some evidence that in certain contexts, gender is transferred to German inanimate cognates when Belgian Dutch speakers are asked to assign German articles to given nouns (Vanhove 2017).

Gender agreement in Dutch occurs with determiners, adjectives, and pronouns. In singular noun phrases (NPs), agreement is marked either on the determiner (in definite NPs) or on the adjective (in indefinite NPs), but never on both. As can be seen in Table 1, the attributive adjective always receives a schwa ending (-e), except in indefinite neuter NPs or NPs that are not preceded by determiners. Distinct gender marking disappears, i.e. is neutralized, when Dutch nouns are used in the plural or in their diminutive form. All plural nouns receive the common determiner ' $d e^{\text {' }}$ and the schwa ending on adjectives (e.g., de blauwe auto's [the cars] and de blauwe boeken [the books]), and all diminutives receive neuter gender marking (e.g., het autootje [the car-little] and het boekje [the book-little] (Haeseryn et al. 1997).

\subsubsection{Lexical gender in German}

In German, nouns are marked as masculine, feminine, or neuter with the articles der (masculine), die (feminine) and das (neuter) (Bußmann/Hellinger 2003). While Dutch has a more frequent common category, German masculine seems to be slightly larger a category (38\%) than feminine (35\%) and neuter (26\%) according to the CELEX corpus (Schiller/Caramazza 2003). German articles are not only declined for gender,

3 As the examples of Oriya and English show, a gender system can erode (Oriya) and eventually be lost (English) (Hellinger/Bußmann (eds.) 2003). It has been argued that the present Dutch gender system is in state of erosion (De Vogelaer 2012; Loerts 2012). 
but also for number and case. For example, der is not only employed as masculine nominative, but also as feminine dative and genitive as well as plural genitive. Moreover, die is not only employed as feminine nominative, but also as feminine accusative and plural nominative. Gender is thus neutralized in plural forms (Bußmann/ Hellinger 2003). Unlike case or number, however, lexical gender is an inherent property of the noun that controls agreement between that noun and syntactically related words. As can be seen in Table 1, in the singular nominative case, definite NPs and many pronouns, such as demonstrative pronouns, only show gender marking on the determiner. For indefinite NPs, gender marking is present on the adjective, but the indefinite determiner also receives the - $e$ suffix when modifying feminine nouns.

While the German system is rather straightforward in the definite singular nominative case, the system becomes less transparent for plurals and/or indefinite NPs. Like in Dutch, the plural definite determiner is not gender marked. Similarly, like Dutch, although more complex, German definite determiners are always declined in the definite NPs and for pronouns, while adjectives in indefinite NPs or NPs without determiners are not declined. For examples including the different cases, the reader is referred to Duden (2006) or Bergmann (2017: chapter 6).

Table 1: Overview of the main agreement targets in Dutch and in the German singular nominative case (English equivalents in italic)

\begin{tabular}{|c|c|c|c|c|}
\hline Language & Gender & Definite Noun Phrase & Indefinite Noun Phrase & Pronouns \\
\hline \multirow[t]{3}{*}{ Dutch } & Common & $\begin{array}{l}\text { de mooie auto } \\
\text { the beautiful car }\end{array}$ & $\begin{array}{l}\text { een mooie auto } \\
\text { a beautiful car }\end{array}$ & $\begin{array}{l}\text { die/deze mooie auto } \\
\text { that beautiful car }\end{array}$ \\
\hline & Neuter & het mooie boek & een mooi boek & dat/dit mooie boek \\
\hline & & the beautiful book & a beautiful book & that beautiful book \\
\hline \multirow[t]{6}{*}{ German } & Masculine & der schöne Garten & ein schöner Garten & dieser schöne Garten \\
\hline & & the beautiful garden & a beautiful garden & that beautiful garden \\
\hline & Feminine & die schöne Schule & eine schöne Schule & diese schöne Schule \\
\hline & & the beautiful school & a beautiful school & that beautiful school \\
\hline & Neuter & das schöne Buch & ein schönes Buch & dieses schöne Buch \\
\hline & & the beautiful book & a beautiful book & that beautiful book \\
\hline
\end{tabular}




\subsubsection{Dutch versus German: differences in transparency and systematicity}

A clear difference between the Dutch and German gender systems concerns the different number and size of categories, but there are also differences in gender assignment. Three ways of assigning inanimate nouns to a gender category have been proposed in the literature: semantic, phonological and morphological (Corbett 1991; Mills 1986; van Berkum 1996). Examples of each of the three can be found in German, but in Dutch, mostly morphological rules are found (Booij 2002). Regarding semantics, for example, German nouns denoting birds are generally masculine while nouns denoting trees or flowers are generally feminine (Szagun et al. 2007). Although not as prominent as the rules in Romance languages, German also has some phonological cues. For example, words ending in nasal consonants are mostly masculine while words ending in - $e$ and -ie are mostly feminine (Mills 1986). Morphological cues in German nouns are, for example, the suffix -ling which can generally be associated with masculine gender and the suffix -keit generally predicting feminine gender (Corbett 1991; Köpcke/Zubin 2009). The Dutch gender assignment system also has a (small) number of suffixes that can be used to assign genders, in line with the original three-way distinction, such as -je for neuter gender (diminutives), -aard for masculine words and -heid for feminine words. These morphological rules, however, tend to include many exceptions (Booij 2002; Haeseryn et al. 1997). Furthermore, in both Dutch and German, in a small number of cases, lexical gender does not match with the biological gender of the referent (see Introduction).

While pronouns in German still mostly agree with the lexical gender of the noun they refer to (albeit with some exceptions), the erosion of the Dutch system, i.e., the loss of the distinction between masculine and feminine nouns, seems to lead to the use of a more semantically based pronominal system. This shift is mostly in favor of the masculine category: many originally feminine nouns, e.g., zon [sun], are nowadays referred to with the masculine pronoun hij [he] in Netherlandic Dutch (Haeseryn et al. 1997). This is also the case for non-diminutive neuter nouns, e.g., het kind [the child]; het masker [the mask] (see Audring 2009). It should be noted, however, that Audring also found some degree of semantic agreement in the consistent German system, which is, like in Dutch, based on lexical gender (for animate nouns) or degrees of individuation of the referent (for inanimate nouns). Compared to German, however, where there is generally a one-to-one correspondence between articles and their related pronouns, Dutch is rather instable and variable: nouns do have a fixed gender, but they are not consistently used with the agreement pattern that corresponds with that gender category. In fact, all possible article-pronouns combinations seem to occur in 
Netherlandic Dutch (Audring/Booij 2009). Because of the relatively scarce amount of gender cues on the noun itself, Dutch and, to a lesser degree, German, are both considered covert gender systems, i.e., systems in which the category to which a noun belongs can hardly be predicted based on phonological or morphological characteristics of that noun (e.g., Booij 2002; Corbett 1991; Haeseryn et al. 1997). The categories that nouns belong to thus largely must be acquired based on cues on agreement targets, but this agreement system is, especially in Dutch, not consistent, nor straightforward. Whether this has any consequences for L1 and/or L2 learners will be discussed in section 3 .

\subsection{Semantic gender for personal nouns in Dutch and German}

Semantic gender relates to the property of non-linguistic maleness or femaleness as encoded in a noun's lexical meaning. Personal nouns may thus be marked as female-specific (e.g., dochter; Tochter [daughter]), male-specific (e.g., meneer; Herr [sir]) or gender-neutral (e.g., persoon; Person [person] (Hellinger/ Bußmann 2001).

\subsubsection{Gender confusion in Dutch}

Gerritsen (2002) writes that Dutch has two types of role nouns: terms that indicate the gender of the person who practices the role (male or female) and terms that do not. Not all personal masculines have a feminine counterpart. In this respect, Dutch differs substantially from German where almost all personal nouns referring to men can be transformed into feminine equivalents by adding the suffix -in (Bußmann/Hellinger 2003). Furthermore, the number of suffixes that can be used to feminize personal nouns denoting men is larger in Dutch than in German (see Table 2). The most productive female-specific suffix in Dutch is - $e$, which especially occurs with loans (assistent-assistente [assistant]); nouns ending in -ing (leerling-leerlinge [pupil]); and some other nouns (echtgenoot-echtgenote [spouse]). Other productive suffixes are: -ster (e.g., voorzitter, voorzitster [chairperson]); -euse and -trice (e.g., presentator, presentatrice [presenter]) - a (e.g., historicus, historica [historian]); -es and -esse (e.g., baron, barones/se [baron/baroness]) -in (e.g., boer, boerin [farmer]). Apart from male and female nouns, Gerritsen (2002) distinguishes a category with gender-neutral terms (with a masculine history) such as dokter [physician]; professor [professor]; psychiater [psychiatrist]. Note that many of these terms end in -er. Like German, Dutch allows for nominalization 
of adjectives (de zieke [the sick person]) and verbs (de reiziger [the traveler]) that supposedly are gender-neutral as well.

Gendered professional titles became subject of debate in the Netherlands in the 1970s (Kool-Smit 1967; Romein-Verschoor 1975), which has currently resurfaced (Peters 2016; Bolle 2017). In 1980, the law prescribed that in personnel advertisements, men and women should be equally visible. However, it has been found that different types of professional names were and are used unsystematically (Gerritsen 2002). At the time, The Ministry of Social Affairs recommended (new) neutral terms (cf. Werkgroep 1982), but the media as well as linguistic circles responded negatively. Formations such as timmer to refer to a carpenter (instead of timmerman or timmervrouw, which mark gender) were considered ridiculous and some linguists argued that the terms were not neutral at all, but only referred to men (e.g., dominee, minister, notaris [vicar, minister, notary]). Van Alphen (1983) and Huisman (1985) therefore advocated gender-specific names for professions. In the end, no official guidelines were determined, but the Dutch Language Union published a volume that presents social and linguistic information about the issue and possibilities to avoid linguistic sexism (de Caluwe/van Santen 2001). Recently, calls for gender-neutral language resurfaced in the Dutch media (Peters 2016; Bolle 2017; Meindertsma/de Bruijn 2017) ${ }^{4}$, although for many professional titles it is still far from clear whether they are (perceived as) gender-neutral. In terms of gender fairness, ample research suggests that female visibility in fe/male pair forms yields more gender fair perceptions in Dutch than neutralizing terms (see section 2.2.3 below), but more research is needed to disentangle these effects.

\subsubsection{Female visibility in German}

Almost all German masculine personal nouns can be made feminine with the feminine suffix -in, as in Student (base, [student]) and Student-in [student-female] (Bußmann/Hellinger 2003). The suffix -in is well established, has no negative connotations and does not indicate lower status. Other feminizing strategies, that are more contested, are coordinated pair forms (Lehrerinnen und Lehrer [teachers-female and teachers-male]) or various forms of abbreviated splitting, sometimes with capital-I (Lehrer/Innen). Nouns ending in -er are

4 In July 2016, the Dutch LGBQT organization announced that the pronoun hen [s/he] won the contest of gender-neutral alternative for hij [he] and $z i j$ [she] (Peters 2016). It is unknown whether and how this pronoun is used in current Dutch. 
taken to be masculine, as in fahr-(base, [drive]), Fahr-er [driver-male] (Bußmann/ Hellinger 2003). The suffixes -ler and -ner are male-specific as well, but may, in addition, be used in generic contexts (i.e., to refer to women as well). There are hardly exceptions to the rule that a noun's gender is invariant. Only a few nouns can be described as genuinely gender-indefinite, such as Person, Kraft, Mensch [person, -force, human]. Such nouns can become gendered though, through adjectival modification (e.g., eine weibliche/männliche Person [a fe-/male person]). Further, there are some occupational terms which are compounds containing -mann or -frau as a second element (e.g., Kaufmann/Kauffrau [salesman/-woman]). Nominalized adjectives and participles may be assigned either of the three genders by the choice of dependent categories. For example, the adjective krank [sick] can be nominalized into der Kranke [the sick person-male]) and die Kranke [the sick person-female] (Bußmann/Hellinger 2003). In contrast with Dutch, the definite article will mark gender after all for these German forms.

Though English guidelines (UNESCO 1999, 2017) emphasize neutralization, German guidelines prioritize female visibility. Bußmann/Hellinger (2003) argue this is a consequence of several factors: the existence of lexical gender; the tendency towards its agreement with semantic gender; and the fact that derivation of feminine personal nouns is embedded in the German word-formation system. Female visibility is mandatory in gender-specific contexts but is also recommended in all contexts that include female referents. Alternative options are usage of gender-indefinite nouns as in Lehrpersonen, Lehrkräfte [teachers] or nominalized plural forms, which do not differentiate lexical and hence referential gender in German, as in Auszubildende [trainees], Drogensüchtige [drug addicts]). In the singular, female visibility must be achieved. However, masculine forms that are part of inanimate compounds are not subject to change: Benutzerhandbuch [user manual]), Führerschein [driving license] (Bußmann/ Hellinger 2003).

Table 2: Noun endings that have been reported to mark gender for Dutch and German singular role nouns

\begin{tabular}{llll}
\hline Language & Feminine ending(s) & Masculine ending(s) & Gender-neutral ending(s) \\
\hline Dutch & $\begin{array}{l}\text {-e-, -ing, -ster, -euse, } \\
\text {-trice, -a, -es, -esse }\end{array}$ & -er & -e; -er \\
\hline German & -in & $\begin{array}{l}\text {-er, -ler, -ner } \\
\text { (e.g., generic in plural) }\end{array}$ & -e \\
\hline
\end{tabular}




\subsubsection{Male generics in Dutch and German}

As noted above, male generics have been an important topic of public debate for both Dutch and German. Male generics are (historically) masculine personal nouns (e.g., doctor, professor, psychiatrist) that are used either generically, i.e., referring to both women and men, or specifically, i.e. referring to only men. German research, that started in the 90s, has convincingly shown that generic use of masculine personal nouns is strongly male-biased (see Horvath et al. 2015 for an overview). These studies arrive at convergent conclusions using different techniques such as sentence completion tasks, reaction time measurements, reading tasks and questionnaires. For Dutch, it is claimed that masculine terms (e.g., medewerker [employee]) and neutralizing terms (e.g., nouns that have no feminine counterparts, arts [doctor], or are inherently gender-neutral (e.g., hoofd [head]), are increasingly used to refer to both women and men (Gerritsen 2002). This claim was supported by De Backer and De Cuypere (2012), who used survey experiments to investigate how German and Belgian Dutch speakers interpret masculine personal nouns used in a referential context. Results suggest that German masculine nouns are more restrictive in potential reference than Dutch nouns. This effect is more pronounced in the singular than in the plural. Not only number, but also lexical type played a role as nonoccupational nouns tended to be more gender-neutral as compared with occupational nouns.

Male- and female-specific forms versus male generics may have a severe impact on visibility and perception of (successful) women (Lassonde/O'Brien 2013). Stahlberg/Szcesny/Braun (2001) for example, asked German participants to write down names of their favorite musicians or athletes. Participants read identical instructions with either a masculine only form (Sportler [male or generic athlete]) or a pair form (Sportlerin/Sportler [female/male athlete]). Results showed that more female personalities were listed in the pair form condition than in the masculine only condition. Similar results have been reported with German and Dutch speaking Belgian 6-year old school children. Vervecken/Hannover/Wolter (2013) examined these children's perceptions of females' and males' success (i.e., who can succeed?) in traditionally male occupations (e.g., lawyer). Results showed that children who read pair forms perceived females' and males' success more equally than children who read the masculine form only. Male generics instead of pair forms may even have an impact on behavior in professional contexts. In a hiring-simulation study in German, for example, decision makers preferred male over female applicants for a high-status leadership position when the position was advertised in the masculine (Geschäftsführer, [CEO-male]) (Horvath/Sczesny 2016). 
In sum, we can distinguish some important (a)symmetries in the expression of semantic gender in Dutch and German. First, where Dutch has about eight suffixes to mark whether a personal noun refers to females or not, German employs only one. German does have a few masculine markers for German singular nouns (-er, -ler and -ner), while the ending -er in Dutch marks masculinity or gender neutrality. These differences are likely bound to the erosion of the Dutch gender system and the lack of official Dutch guidelines for professional terms in contrast with clearer rules and priority of female visibility in German. Perception of male generics has been well-investigated for German, but should be examined in more detail for Dutch.

\section{Gender acquisition and processing in Dutch and German}

Differences in the expression of gender in Dutch and German and the instability of the Dutch gender may well lead to differences in both the processing and the acquisition of gender in the two languages, which may in turn explain observed patterns of language variation and change. Gender is also an intriguing phenomenon when related to bilingualism as it is realized differently in German and Dutch. Potential changes in perception when shifting language system can shed light on the question of whether it is possible to learn a completely new or different lexical gender system in later stages of life and what the influence of the L1 might be in this process. So far, we have discussed the Dutch and German systems and have addressed some studies that employed offline research techniques (questionnaires, categorization tasks etcetera). Here we will also address studies that have employed online research techniques: eye tracking and ERPs. The advantage of the latter techniques over the former is that they measure online processes, i.e., processing of language as speech unfolds, instead of an answer or decision that cannot reveal the processes that led to the product.

\subsection{L1 Acquisition and the processing of gender}

When do Dutch and German children acquire their lexical gender system? While learners of German can rely on semantic, morphological, and phonological cues on the noun, learners of Dutch can only rely on morphosyntactic cues, i.e., the gender agreement system, to track down a noun's gender category. As explained in section 2.1, however, these morphosyntactic cues are not consistently nor reliably 
present in the Dutch input. Dutch common gender marking, for example, is used to conjugate words related to any noun used in the plural (as feminine die can precede plurals in German), while neuter gender marking can be used with both common and neuter nouns when they are used in diminutive form. The absence of cues and the absence of a one-on-one relationship between gender marking and gender in Dutch likely forces children to acquire Dutch gender word by word (Unsworth 2008). This section will investigate whether this is indeed the case by comparing studies looking at production, comprehension and online processing of lexical gender in Dutch and German.

\subsubsection{L1 acquisition of gender in Dutch versus German: production studies}

In line with the above reasoning, Dutch L1 speakers have indeed been shown to have difficulty acquiring Dutch gender and have been shown to overgeneralize the more frequent common determiner de until, and sometimes even beyond, the age of 6 (Blom/Polišenkà/Weerman 2008; Cornips/van der Hoek/Verwer 2006; Hulk/Cornips 2006a, b; De Houwer/Gillis 1998; van der Velde 2004). This acquisition pattern is in stark contrast with the pattern observed in German native children, who have been shown to use the correct articles in their L1 at the age of 3 to 4 (Mills 1986; Szagun et al. 2007). In contrast with Dutch children, German children make relatively few mistakes when producing gender marking and, when they do not know the gender of the noun, they tend to omit the articles more often than overgeneralize one of the available determiners (Mills 1986). The feminine definite singular and plural determiner die is, however, sometimes overgeneralized (Bewer 2004; Mills 1986), but the degree of overgeneralization is not comparable to the over-occurrence of common gender marking in Dutch. Moreover, systematic overgeneralization is generally not reported for monolingual speakers of other gendered languages, such as French and Spanish (Franceschina 2005).

In both Dutch and German, but also in many other gendered languages, agreement between the definite article and the noun is acquired before agreement between the adjective and the noun. Before being able to accurately and consistently use the agreement rules, learners thus seem to put knowledge of a noun's gender in place first. The first phonetic rule for inanimate nouns that is represented in the German child's vocabulary is the association of the - $e$ ending with feminine gender (e.g., die Erde [the earth]), which appears to be the most frequent rule with the fewest exceptions. In line with the order of acquisition in Dutch, i.e, common before neuter and definite articles before adjectival inflection, Mills (1986: 85) concludes that the order of acquisition in German is related to the 
scope of the rule and the number of exceptions. The asymmetry and the relatively scarce availability of rules and relatively frequent occurrence of exceptions to those rules in the Dutch gender assignment system is likely to partly explain the relatively late acquisition of Dutch gender as compared to German that is seen in production studies.

\subsubsection{L1 acquisition of gender in Dutch versus German: comprehension and processing}

In comparison with production studies, the relatively scarce amount of studies incorporating comprehension tasks have only partly added evidence to the relatively late acquisition of Dutch grammatical gender. Using a grammaticality judgement task with determiner noun combinations, Unsworth/Hulk (2010a, b) showed a mean accuracy of $70 \%$ for 4- to 6-year old Dutch children and, in line with production data, these children accepted ungrammatical neuter determiner noun combinations more often than ungrammatical common NPs. While there is not a lot of data from children between 6- and 11-years of age, Dutch children's judgement of gender marked NPs has been shown to reach adult L1-like ceiling level around the age of 11 (Cornips/Hulk 2008). Interestingly, when metalinguistic knowledge is not tested, as is the case with a preferential looking paradigm, 2-year old Dutch children have been found to use the common determiner de to more quickly locate a target object (Johnson 2005), which corroborates later findings using eye tracking with a visual world paradigm that common gender marking is used by adults to facilitate comprehension (Loerts/Wieling/Schmid 2013). Although only found for common nouns in Dutch, such a gender effect is in line with studies showing that Spanish 2- to 4-year olds, like adults, can use informative gender marking to identify a target referent (Lew-Williams/Fernald 2007, 2010).

To further investigate the acquisition process during the apparent transition from non-targetlike to targetlike use of, particularly, neuter gender in Dutch, Brouwer/Sprenger/Unsworth (2017) recently tested 4- to 7-year olds using a visual world paradigm. They showed that children who correctly used neuter gender in production behaved like Dutch adults and used gender marking to anticipate, i.e., to predict, the upcoming noun. The children who still made a lot of neuter gender mistakes in production could use gender marking to facilitate comprehension (i.e., to speed up comprehension after hearing the determiner), but not to anticipate upcoming targets. Contrary to the findings by Johnson (2005) and Loerts/Stowe/Schmid (2013) that only common gender might have such an effect, which has been explained by the fact that het is less informative as it can precede 
any noun in its diminutive form, Brouwer and colleagues found the anticipatory effect only for neuter gender marking. While this difference might be affected by the visual world paradigm with 4 instead of 2 pictures used by Loerts/Stowe/ Schmid (2013), the combined results additionally reveal information about the potential developmental pattern of gender acquisition in Dutch. Brouwer/ Sprenger/Unsworth (2017) found that 2-year olds may first only use de (Johnson 2005; Unsworth 2008) after which they acquire and temporarily only use het in a facilitative fashion before being able to also use gender marking anticipatorily (Brouwer/Sprenger/Unsworth 2017). The predictive power of gender in Dutch has not only been found to be asymmetrical when compared to other languages, but the effect also seems a lot smaller than the predictive anticipatory effects of all three gender marked articles that has been reported for German in adults (Hopp 2016). To the authors' knowledge, the use of German gender marking to predict upcoming nouns has only been tested and established for 8- and 9-year olds (Lemmerth/Hopp 2019), but not for younger children.

\subsection{Gender in L2 acquisition and processing}

\subsubsection{L2 acquisition of gender in Dutch versus German: production studies}

For L2 Dutch, like L1 Dutch as discussed in section 3.1, speech production studies found that L2 learners overproduce de instead of het, as shown for Moroccan children and Moroccan, Turkish, English, Polish and deaf adults learning Dutch (Blom/Polišenkà/Weerman 2008; van Emmerik et al. 2009; Loerts 2012; Unsworth 2008). An overview by Cornips/Hulk (2008) revealed that the overextension of de in Dutch also holds for children simultaneously acquiring Dutch with French, Akan, Ewe and Surinamese. They point towards a prominent role for "lengthy and intensive input" in explaining acquisition differences between less and more successful bilingual children. ${ }^{5}$ Lemhöfer/Spalek/Schriefers (2008) report that the L1 affected assignment of gender in the L2 for adult German learners of L2 Dutch. This remained the case even after receiving training on gender assignment (Lemhöfer/Schriefers/Hanique 2010).

For L2 German, production difficulties have been reported for English, Afrikaans and Italian adult speakers (Bianchi 2013; Bobb/Kroll/Jackson 2015; Bordag/

5 Cornips (2008) also points out that young immigrants in the Netherlands are consciously overextending Dutch de [the] as an identity marker. 
Opitz/Pechmann 2006; Ellis/Conradie/Huddlestone 2012). Ellis/Conradie/Huddlestone (2012) found that Italian learners outperformed English and Afrikaans speakers, which they attribute to "deep" L1 transfer of grammatical gender (since Italian and German both know lexical gender, but the systems are not congruent). Bianchi (2013) also points to language-internal factors, as well as amount of input, to explain deviations from target gender assignment for Italian-German bilinguals. Eichler/Jansen/Müller (2012) report on bilingual child acquisition of German with French, Italian and Spanish and showed that bilingual children can acquire gender systems in both languages without any delays. Yet children's accuracy can be predicted based on language dominance and German is the most problematic system to acquire. The authors found that accuracy on neuter gender is lower in bilingual than monolingual German, suggesting that simultaneous acquisition of a two- and three-gender system has delaying effects for target-like neuter marking. Salamoura/ Williams (2007) also found L1 effects for adult Greek learners in L2 German gender assignment. Nouns that had the same gender in both languages were translated faster than nouns with different genders, and gender-incongruent cognates yielded more errors. To our knowledge, few studies have focused on L2 production of gendered personal nouns (but see Urbanek et al. 2017; De Vogelaer et al. (this volume), both showing transfer effects in German L2 Dutch learners' pronoun use).

\subsubsection{L2 acquisition of gender in Dutch versus German: comprehension and processing}

Hopp (2013) examined how English L2 German learners assign gendered determiners to inanimate nouns and how these are comprehended in real-time. Results showed contingencies between accuracy in lexical assignment in production and target-like processing in comprehension (as measured using eye tracking). According to Hopp, this argues against a representational and processing deficit in late L2 learners. Eye tracking studies using a visual world paradigm, like Hopp (2013), have examined whether L2 learners, like native adults (see section 3.1.2), use grammatical gender to facilitate L2 comprehension. Results suggest that both L2 Dutch as well as L2 German learners experience challenges in this respect. Loerts (2012) for example, found that Polish (a language with no articles) late learners of L2 Dutch cannot pre-activate L2 grammatical gender information (in articles) to facilitate comprehension of inanimate (object) nouns nor do they (in)accurately use L1 gender categories (as previously found by e.g., Weber/Paris 2004). For L2 German, using a similar paradigm, Hopp (2016) investigated whether English L2 German learners use grammatical gender for predictive processing and found that knowledge of gender assignment is a prerequisite for using gender 
marking predictively. Non-target gender assignment led to erroneous gender prediction and was therefore abandoned. This effect was replicated with L1 German speakers when they hear input with gender mistakes: the low reliability in target-like gender assignment leads them to abandon the use of grammatical gender as predictive cue (Hopp 2016). Sabourin/Stowe/de Haan (2006) examined gender assignment for advanced German, English and Romance learners of L2 Dutch. They concluded that L2 acquisition of lexical gender was mostly affected by morphological similarity of gender marking in the L1, with high accuracy for German speakers as there is relatively more overlap between German and Dutch.

The online processing of gender has more recently increasingly been assessed using event-related potentials (ERPs), which are changes in brain activity that show when specific aspects of language are processed. This technique has repeatedly shown that semantic violations or unexpectancies are generally evoking an N400, a negative going wave around $400 \mathrm{~ms}$, while morphological and syntactic violations and difficulties generally elicit a positive deflection around $600 \mathrm{~ms}$, known as the P600. Grammatical gender violations have consistently been found to elicit a P600 reflecting syntactic re-analysis or repair in various languages including Dutch (e.g., Loerts/Stowe/Schmid 2013) and German (Gunter/ Friederici/Schriefers 2000; Davidson/Indefrey 2009). Late L2 learners' processing of L2 gender violations has been shown to be affected by L1, with both the presence as well as the similarity of gender systems being a prerequisite for nativelike processing (Sabourin/Stowe 2008). Interestingly, highly proficient L2 learners with a completely different gender system (i.e, Polish) have been found to show a reduced and delayed $\mathrm{P} 600$, but only in response to violations of common gender (Loerts 2012). This latter result is in line with many of the other studies discussed above showing difficulty especially in the acquisition of Dutch neuter gender.

An understudied group of learners, especially with the use of online measures, are early bilinguals. The general idea is that simultaneous bilinguals will eventually catch up with their monolinguals peers, but an ERP study on Dutch gender showed that simultaneous bilinguals with Turkish (which has no gender) and Dutch as L1s only show a reduced P600 when compared to their "monolingual" peers with over half of them performing at chance level when judging grammatical gender violations offline (Seton 2011). Similarly, while 8-year old simultaneous Russian-German bilinguals have been shown to be able to use German gender to predict upcoming words, their early successive bilingual peers could only use German gender cues to predict nouns if they shared gender in German and Russian (Lemmerth/Hopp 2019). These combined results suggest an important role for the L1 that requires more attention in future research.

Another line of research focused on pronominal gender for nouns (e.g., Lamers et al. 2008). Ellert (2011) studied relative pronoun resolution (e.g., hij/ 
er [he]; die/der [he]) in L1 and L2 Dutch and German discourse for both animate (e.g., Peter) and inanimate nouns, using ERPs. She found that pronoun resolution was affected by order of mention and information structure of the antecedent clause, but animacy had no effect in L1 Dutch. This indicates that personal and demonstrative pronouns exhibit the same level of (non)ambiguity in Dutch, which contrasts with German, where personal pronouns were resolved earlier after animate antecedents. Proficiency level was an important predictor for native-like processing, but both Dutch L2 German as well as German L2 Dutch learners showed both timing as well as resolution differences for animate entities when compared with L1 speakers. Urbanek et al. (2017) investigated production and perception of pronominal gender in German L2 Dutch learners for concrete mass nouns (e.g., sugar, grass etc.). In current Netherlandic Dutch, the dominant type of pronoun in reference for de-words is hij [he] (Haeseryn et al. 1997). One result showed that in contrast with L1 Dutch speakers, German L2 Dutch learners used $z i j / z e$ [she] to describe de-words with feminine German counterparts in 64.9 percent of the cases, which can be explained by L1 transfer. Yet, acceptability data showed that, in contrast with female preference in the production data, variation in pronoun use was deemed acceptable by L2 learners. De Vogelaer et al. (this volume) present new data of Austrian and German learners of L2 Dutch on the same topic.

Comprehension of animate nouns seems less well-investigated in L2 acquisition. For example, we know of no studies investigating L2 acquisition of gender marking on personal noun endings (as outlined Table 2). Though these words appear frequently in the input (Gerritsen 2002; Hellinger/Motschenbacher (eds.) 2015) and adult L2 learners will encounter them, for example, in L2 textbook chapters. Some work on German has focused on the interaction of lexical gender and names for role nouns or nouns for stereotypical fe/male professions. Sato/ Gabriel/Gygax (2016), using a sentence evaluation task, examined how nominalized adjectives (e.g., die Konsumierenden [those that consume]) with grammatically masculine nouns (e.g., die Käufer [the buyers]) induce male representations in French-German bilinguals. They showed that a masculine bias persisted when participants read masculine plural forms, but that nominalized forms can attenuate this male bias, even for nonnative speakers. In another study, Sato/Gygax/ Gabriel (2016) investigated French-German bilingual speakers with a visual world eye tracking task. They presented speakers with stereotypical, plural role nouns and plural determiners that have a generic meaning in French and a feminine connotation in German (e.g., les techniciens, die Techniker [the technicians]). Participants judged whether a pair of faces showing two men or a man and a woman could represent the presented language. Results showed no effects of the determiner, but an interaction of face pairs and stereotypes, where the 
preference for male face pairs that followed stereotypical male nouns was the most pronounced. This aligns with claims that L2 learners rely primarily on non-structural lexical semantic and pragmatic cues when comprehending their L2 (Clahsen/Felser 2006).

In sum, grammatical gender production difficulties seem to occur both in L1 and L2 Dutch and L2 German, and these difficulties seem to be related to proficiency, input and the presence and degree of similarity of an L1 gender system. L2 learners can use grammatical gender to facilitate comprehension, but only when they are highly proficient and hardly make mistakes. While late learners have been studied relatively extensively in this field of research, little is still known about comprehension and processing of gender in early bilinguals. For personal (pro)nouns, production results show that German L2 Dutch learners use female pronouns to refer to nouns with common gender, while L1 Dutch speakers use male pronouns, which can be explained by L1 transfer. Research has also shown that for resolution of pronouns, animacy affects how (fast) L1 and L2 Dutch and German speakers resolve comprehension. When interpreting professional names, stereotypical knowledge affects speakers' representations to a much larger degree that grammatical knowledge. It has also been shown that gender-neutral nominalized forms, can attenuate male bias, suggesting that human gender categories in language can be (un)learned.

\section{Gaps in psycholinguistic, Dutch-German gender research}

The previous sections have outlined descriptive and psycholinguistic research into gender in Dutch and German. When it comes to research into bilingualism, language and gender in general, Pavlenko (2014: xiii) described that "the research on (grammatical) gender [...] is limited to a handful of psycholinguistic studies documenting effects (or lack thereof) in artificial tasks and it is not clear what, if any, implications these findings have for habitual thought". The special issue by Garnham et al. (2016), which addresses effects of semantic gender in German, but not in Dutch speaker cognition, and themes such as gender-neutral language and its effects on reducing stereotyping and discrimination (Szcesny/Formanowicz/ Moser 2016), shows that in this area, many questions concerning both L1 and L2 speakers remain unanswered as well. In addition, recent public debates on genderneutral language in German and Dutch (Vermeulen 2018) indicate the necessity of further research. The present section therefore presents impulses regarding content and methodology for future studies. 


\subsection{Interpretation of personal nouns in L1 and L2 Dutch}

With respect to semantic gender, we find that, in contrast to gendered definite articles (e.g., German der/die/das (the)) and inanimate nouns, gender for animate (role) nouns (e.g., nurse, technician) has been less frequently researched, especially for (Netherlandic) Dutch. In addition, there are few Dutch studies into so-called male generics (e.g., Dutch burgemeester [mayor]), which contrasts with the substantial German body of research on the topic. For the Dutch public to determine what is "gender-neutral" language, we need more studies. We need, for example, studies like the one by De Backer/De Cuypere (2012), that identify non-/occupational terms and whether they are perceived as fe/male or gender-neutral, covering a large number and range of terms (De Backer/De Cuypere investigated only sixteen Belgian-Dutch terms). This can be done by survey experiments, like De Backer/De Cuypere (2012) did, or sentence completion paradigms, reading tasks and reaction time measurements (e.g., see German studies like Horvath et al. 2016). However, online measures, for example eye tracking, provide an excellent means too to discover whether individuals look towards fe/male persons upon hearing a given role noun (see Sato/Gygax/Gabriel 2016). Further, studies that reveal effects of male generics versus gender-neutral alternatives on decision making processes are needed for Dutch. The hiring simulation study for German by Horvath/Szcesny (2016) for example, could be replicated for Dutch; or the study into effects of language on perception of fe-/ male success by Vervecken/Hannover/Wolter (2013) could be replicated with Dutch children. Focusing on L2 learners, we need to identify whether and what forms are presented to them in what manner in L2 Dutch and German text books (see Koster/Iding 2019); whether fe-/male noun endings are comprehended as such (with/out instruction) and whether target-like comprehension is more easily established when L1 categories are similar to L2 categories (e.g., male -er noun ending in Dutch vs. German) as compared with different L2 categories (e.g., Dutch female noun endings - $e$, -ing, -ster, -euse, -trice, - $a$, -es, -esse vs. German female ending -in).

\subsection{Acquisition of gender in Dutch vs. German}

The acquisition of Dutch lexical gender seems, when compared to German, relatively difficult for both L1 speakers and L2 learners. Most studies have, however, looked at production data only, and there is evidence suggesting that comprehension and production of gender may not always go hand in hand. Ideally, 
future studies should combine both production and comprehension measures, but also incorporate more longitudinal designs with emphasis on the age range from 4 to 11 in which Dutch gender acquisition appears to move to a target-like system. Comprehension studies should ideally resemble real life, thus covering larger pieces of text instead of words and single sentences. Simultaneous and early successive bilinguals are an understudied group and their processing of language has long been thought to (eventually) match those of monolinguals. Recent studies investigating brain activity in response to gender violations suggest that this is not always the case (Seton 2011) and the L1 of these early bilinguals seems to have an impact (Lemmerth/Hopp 2019). Although many studies focusing on late L2 learners have already pointed towards the crucial role of the L1 (e.g., Sabourin/Stowe 2008), these studies often suffer from high interindividual heterogeneity (e.g., age of acquisition, L2 proficiency, aptitude, etc.). More studies with successive, but especially with simultaneous bilinguals are needed as these can provide important evidence concerning the impact of one language on another language during different stages of acquisition. The role of stereotypical knowledge about fe/male roles is another important topic to be explored further, with potential for online measures. As ERPs can reveal the activation of stereotypical information (e.g., Misersky 2017), they could be exploited to reveal whether certain non-/ stereotypical nouns trigger certain brain patterns in Dutch and German as well. Furthermore, such measures might eventually be used to examine potential transfer effects of cultural and linguistic stereotypical information in L2 learners of Dutch and German.

\subsection{L2 Acquisition of gender using online measures}

Research on L2 acquisition with online processing measures has not emerged until recently for both languages. It is recommendable that more different language combinations are examined, as the lack of or nature of a gender system in the L1 is an important candidate for positive or negative transfer. Direct comparisons of Dutch and German and potential lexical activation of L1 categories during the processing of L2 in different stages are needed. An interesting candidate for this is the interlingual homophone die, combined with gender-neutral personal nouns, that functions as grammatically female definite article in German (e.g., die Blinde [the blind person]) and as gender-neutral demonstrative in Dutch (e.g, die blinde [that blind person]; see Table 1). In case German L2 Dutch learners adhere to L1 German grammatical gender when comprehending L2 Dutch die blinde, an eye tracking visual world study could reveal whether a female person is the preferred candidate to fixate (Koster et al. 2019). 
In addition, it could be further explored whether and to what degree L2 learners use their L1 gender system to predict upcoming nouns and what the influence in of similarities between the gender systems. Some visual world paradigm studies with other languages than Dutch and German have shown that L1 gender categories are transferred to anticipate upcoming nouns in the L2 (Weber/Paris 2004), but similar transfer effects were not found for late Polish L2 Dutch learners (Loerts 2012). Whether it is the typological difference related to the absence of determiners in Polish or lack of overlap in gender categories that has caused the absence of L1 transfer could be studied in more detail in the future. For example, future studies could determine whether L2 Dutch learners with L1s that do mark gender on articles, but that differ in terms of their similarity to Dutch (e.g, Italian, Spanish, French, German) face fewer difficulties with Dutch gender than Polish learners as shown by online measures revealing the processing of language as the input unfolds. Finally, we need more real-time studies on the processing of morphosyntactic cues in different types of bilingual children, especially for simultaneous and successive bilinguals.

\section{Conclusions}

The aim of the present paper was to provide an up-to-date literature review on linguistic gender in Dutch and German and provide impulses for further psycholinguistic work. We have discussed feminine suns and masculine moons; German women that are perceived as less fit job candidates because of male "generic" language; German and Dutch speaking children that face difficulties when they must describe objects with gendered articles; and gender similarities and differences across German and Dutch, that may benefit, but also confuse adult foreign or second language learners. Gaining a better understanding of the mechanisms and processes that underlie these outcomes can help, for example, in the design of L2 curricula or governmental or newspaper language policies concerning inclusive language. But most of all, present and future psycholinguistic studies into gendered language, can provide us with insight into our own language behaviors and that of people around us. In this way, we can deal with everyone's linguistic and cognitive challenges in a knowledgeable manner. 


\section{References}

Athanasopoulos, Panos/Bylund, Emmanuel/Montero-Melis, Guillermo/Damjanovic, Ljubica/ Schartner, Alina/Kibbe, Alexandra/Riches, Nick/Thierry, Guillaume (2015): Two languages, two minds: Flexible cognitive processing driven by language of operation. In: Psychological Science 26, 4. 518-526.

Audring, Jenny (2006): Genusverlies en de betekenis van voornaamwoorden. In: Hüning, Matthias/Verhagen, Arie/Vogl Ulrike/van der Wouden, Ton (eds.): Nederlands tussen Duits en Engels. Handelingen van de workshop op 30 september en 1 oktober 2005 aan de Freie Universität Berlin. (= SNL-reeks 15). Leiden: Stichting Neerlandistiek Leiden. 71-88.

Audring, Jenny (2009): Reinventing pronoun gender. Utrecht: LOT.

Audring, Jenny/Booij, Geert (2009): Genus als probleemcategorie. In: Taal en Tongval 61, 1. 13-37.

Bergmann, Christopher (2017): Facets of native-likeness: First-language attrition among German emigrants to Anglophone North America. Dissertation. Groningen: University of Groningen.

Bewer, Franziska (2004): Der Erwerb des Artikels als Genus-Anzeiger im deutschen Erstspracherwerb. In: ZAS Papers in Linguistics 33. 87-140.

Bianchi, Giulia (2013): Gender in Italian-German bilinguals: A comparison with German L2 learners of Italian. In: Bilingualism: Language and Cognition 16, 3. 538-557.

Blom, Elma/Polišenkà, Daniela/Weerman, Fred (2008): Articles, adjectives and age of onset: The acquisition of Dutch grammatical gender. In: Second Language Research 24, 3. 297-331.

Bobb, Susan/Kroll, Judith/Jackson, Carrie (2015): Lexical constraints in second language learning: Evidence on grammatical gender in German. In: Bilingualism: Language and Cognition 18. 502-523.

Bolle, Joram (2017): NS vervangt “dames en heren” door "reizigers". NRC. www.nrc.nl/nieuws/ 2017/07/28/ns-vervangt-dames-en-heren-door-reiziger (last accessed: 24-1-2018).

Booij, Geert (2002): The morphology of Dutch. Oxford/Berlin: Oxford University Press.

Bordag, Denisa/Opitz, Andreas/Pechmann, Thomas (2006): Gender processing in first and second languages: The role of noun termination. In: Journal of Experimental Psychology: Learning, Memory and Cognition 32, 5. 1090-1101.

Boroditsky, Lera/Schmidt, Lauren/Philipps, Webb (2003): Sex, syntax, and semantics. In: Gentner, Dedre/Goldin-Meadow, Susan (eds.): Language in mind: Advances in the study of language and thought. Cambridge, MA: MIT Press. 61-80.

Brouwer, Susanne/Sprenger, Simone/Unsworth, Sharon (2017): Processing grammatical gender in Dutch: Evidence from eye movements. In: Journal of Experimental Child Psychology 159. 50-65.

Bußmann, Hadumod/Hellinger, Marlis (2003): Engendering female visibility in German. In: Hellinger/Bußmann (eds.). 141-174.

Clahsen, Harald/Felser, Claudia (2006): Grammatical processing in language learners. In: Applied Psycholinguistics 27, 1. 3-42.

Corbett, Greville (1991): Gender. Cambridge: Cambridge University Press.

Cornips, Leonie (2008): Loosing grammatical gender in Dutch: the result of bilingual acquisition and/or an act of identity? In: International Journal of Bilingualism 12, 1. 105-124.

Cornips, Leonie/Hulk, Aafke (2008): Factors of success and failure in the acquisition of grammatical gender in Dutch. In: Second Language Research 24, 3. 267-295. 
Cornips, Leonie/Van der Hoek, Mara/Verwer, Ramona (2006): The acquisition of grammatical gender in bilingual child acquisition of Dutch (by older Moroccan and Turkish children). The definite determiner, attributive adjective and relative pronoun. In: van de Weijer, Jeroen/ Los, Bettelou (eds.): Linguistics in the Netherlands 23. 40-51.

Davidson, Douglas/Indefrey, Peter (2009): An event-related potential study on changes of violation and error responses during morphosyntactic learning. In: Journal of Cognitive Neuroscience 21, 3. 433-446.

De Backer, Maarten/De Cuypere, Ludovic (2012): The interpretation of masculine personal nouns in German and Dutch: A comparative experimental study. In: Language Sciences 34, 3. 253-268.

De Caluwe, Johan/Van Santen, Ariane (2001): Gezocht: Functiebenamingen (M/V). Wegwijzer voor vorming en gebruik van Nederlandse functiebenamingen. The Hague: SDU Uitgevers.

De Houwer, Annick/Gillis, Steven (1998): Dutch child language: An overview. In: Gillis, Steven/ De Houwer, Annick (eds.): The acquisition of Dutch. (= Pragmatics \& Beyond/New Series 52). Amsterdam: John Benjamins. 1-100.

De Vogelaer, Gunther (2012): Frequency, conservative gender systems, and the languagelearning child: Changing systems of pronominal reference in Dutch. In: Divjak, Dagmar/ Gries, Stefan (eds.): Frequency effects in language learning and processing. (= Trends in Linguistics. Studies and Monographs 244,1). Berlin/New York: De Gruyter Mouton. 109-144.

Dryer, Martin/Haspelmath, Matthew (eds.) (2013): The world atlas of language structures online. Leipzig: Max Planck Institute for Evolutionary Anthropology. http://wals.info (last accessed: 24-1-2018).

Duden (2006): Der Duden in zwölf Bänden. Vol. 4: Die Grammatik. Unentbehrlich für richtiges Deutsch. 6th edition. Mannheim: Dudenverlag.

Eichler, Nadine/Jansen, Veronika/Müller, Natascha (2012). Gender acquisition in bilingual children: French-German, Italian-German, Spanish-German and Italian-French. In: International Journal of Bilingualism 17, 5. 550-572.

Ellert, Miriam (2011): Ambiguous pronoun resolution in L1 and L2 German and Dutch. PhD Thesis. Nijmegen: Radboud Universiteit.

Ellis, Carla/Conradie, Simone/Huddlestone, Kate (2012): The acquisition of grammatical gender in L2 German by learners with Afrikaans, English or Italian as their L1. In: Stellenbosch Papers in Linguistics 41. 17-27.

Everett, Caleb (2013). Linguistic relativity: Evidence across languages and cognitive domains. (= Applications of Cognitive Linguistics 25). Berlin: De Gruyter Mouton.

Franceschina, Florencia (2005): Fossilized second language grammars. The acquisition of grammatical gender. (= Language Acquisition \& Language Disorders 38). Amsterdam: Benjamins.

Garnham, Alan/Oakhill, Jane/Von Stockhausen, Lisa/Sczesny, Sabine (2016): Editorial: Language, cognition and gender. In: Frontiers in Psychology 7. 772.

Gerritsen, Marinel (2002): Towards a more gender-fair usage in Netherlands Dutch. In: Hellinger/ Bußmann (eds.). 81-108.

Gunter, Thomas/Friederici, Angela/Schriefers, Herbert (2000): Syntactic gender and semantic expectancy: ERPs reveal autonomy and late interaction. In: Journal of Cognitive Neuroscience 12, 4. 556-568.

Haeseryn, Walter/Romijn, K./Geerts, Guido/de Rooij, Jaap/van den Toorn, M.C. (1997): Algemene Nederlandse Spraakkunst. 2nd completely revised edition. Groningen: Martinus Nijhoff.

Hellinger, Marlis/Bußmann, Hadumod (2001): Gender across languages: The linguistic representation of women and men. In: Hellinger/Bußmann (eds.). 1-26. 
Hellinger, Marlis/Bußmann, Hadumod (eds.) (2001): Gender across languages. Vol. I. Amsterdam: Benjamins.

Hellinger, Marlis/Bußmann, Hadumod (eds.) (2002): Gender across languages. Vol. II. Amsterdam: Benjamins.

Hellinger, Marlis/Bußmann, Hadumod (eds.) (2003): Gender across languages. Vol. III. Amsterdam: Benjamins.

Hellinger, Marlis/Motschenbacher, Heiko (eds.) (2015): Gender across languages. Vol. IV. Amsterdam: Benjamins.

Hopp, Holger (2013): Grammatical gender in adult L2 acquisition: Relations between lexical and syntactic variability. In: Second Language Research 29, 1 (Special Issue: Morphology in L2 Acqusition). 33-56.

Hopp, Holger (2016). Learning (not) to predict: Grammatical gender processing in second language acquisition. In: Second Language Research 32, 2. 277-307.

Horvath, Lisa/Merkel, Elisa/Maass, Anne/Sczesny, Sabine (2015): Does gender-fair language pay off? The social perception of professions from a cross-linguistic perspective. In: Frontiers in Psychology 6.1-12.

Horvath, Lisa/Sczesny, Sabine (2016): Reducing women's lack of fit with leadership positions? Effects of the wording in job advertisements. In: European Journal of Work and Organizational Psychology 25, 2. 316-328.

Huisman, Joke (1985): Over verschil in gelijkheid en gelijkheid in verschil. In: De Gids 148. 777-783.

Hulk, Aafke/Cornips, Leonie (2006a): Neuter gender and interface vulnerability in child L2/2L1 Dutch. In: Unsworth, Sharon/Parodi, Teresa/Sorace, Antonella/Young-Scholten, Martha (eds.): Paths of development in L1 and L2 acquisition. In honor of Bonnie D. Schwartz. (= Language Acquisition \& Language Disorders 39). Amsterdam: Benjamins. 107-134.

Hulk, Aafke/Cornips, Leonie (2006b): Between 2L1- and child L2 acquisition: An experimental study of bilingual Dutch. In: Lleó, Conxita (ed.): Interfaces in multilingualism. Acquisition and representation. (= Hamburg Studies on Multilingualism 4). Amsterdam/Philadelphia: Benjamins. 115-138.

Johnson, Elizabeth (2005): Grammatical gender and early word recognition in Dutch. In: Brugos, Alejna/Clark-Cotton, Manuella/Ha, Seungwan (eds.): Proceedings of the 29th Boston University Conference on Language Development. Sommervile, MA: Cascadilla Press. 320-330.

Kool-Smit, Joke (1967): Het onbehagen bij de vrouw. In: De Gids 130, 9-10. 267-282.

Koster, Dietha/Iding, Chiara (2019): Van typiste naar ingenieur? Inzichten uit 50 jaar representaties van gender en beroep in NT2-tekstboeken (1974-2017). In: Dutch Journal of Applied Linguistics. https://doi.org/10.1075/dujal.18014.kos (last accessed: 17-10-2019).

Koster, Dietha/Urbanek, Lukas/Kötterhenrich, Gelieza/Bölte, Jens (2019): Interlingual homophones affect human gender representations in language learners - evidence from eye tracking. Conference lecture at: Kontrast \& Opposition/Contrast \& Opposition. 41. Jahrestagung der Deutschen Gesellschaft für Sprachwissenschaft/41st Annual Conference of the German Linguistic Society. Universität Bremen, 06.-08.03.2019.

Köpcke, Klaus-Michael/Zubin, David (2009): Genus. In: Hentschel, Elke/Vogel, Petra M. (eds.): Deutsche Morphologie. Berlin: De Gruyter. 132-154.

Lamers, Monique/Jansma, Bernadette/Hammer, Anke/Münte, Thomas (2008): Differences in the processing of anaphoric reference between closely related languages: Neurophysiological evidence. In: BMC Neuroscience 9.1-13.

Lassonde, Karla/O'Brien, Edward (2013): Occupational stereotypes: Activation of male bias in a gender-neutral world. In: Journal of Applied Social Psychology 43, 2. 387-396. 
Lemhöfer, Kristin/Schriefers, Herbert/Hanique, Iris (2010). Native language effects in learning second-language grammatical gender: A training study. In: Acta Psychologica 135, 2. 150-158.

Lemhöfer, Kristin/Spalek, Katharina/Schriefers, Herbert (2008). Cross-language effects of grammatical gender in bilingual word recognition and production. In: Journal of Memory and Language 59, 3. 312-330.

Lemmerth, Natalia/Hopp, Holger (2019): Gender processing in simultaneous and successive bilingual children: Cross-linguistic lexical and syntactic influences. In: Language Acquisition 26, 1. 21-45.

Lew-Williams, Casey/Fernald, Anne (2007): Young children learning Spanish make rapid use of grammatical gender in spoken word recognition. In: Psychological Science 18, 3. 193-198.

Lew-Williams, Casey/Fernald, Anne (2010): Real-time processing of gender-marked articles by native and non-native Spanish speakers. In: Journal of Memory and Language 63, 4. 447-464.

Loerts, Hanneke (2012). Uncommon gender: Eyes and brains, native and second language learners \& grammatical gender. (= Groningen Dissertations in Linguistics 110). Groningen: University of Groningen.

Loerts, Hanneke/Stowe, Laurie/Schmid, Monika (2013): Predictability speeds up the re-analysis process: An ERP investigation of gender agreement and cloze probability. In: Journal of Neurolinguistics 26, 5.561-580.

Loerts, Hanneke/Wieling, Martijn/Schmid, Monika (2013): Neuter is not common in Dutch: Eye movements reveal asymmetrical gender processing. In: Journal of Psycholinguistic Research 42, 6. 551-570.

Meindertsma, Ben/de Bruijn, Christian (2017): Tientallen gemeenten overwegen "genderneutraal” beleid. NOS. https://nos.nl/artikel/2186208-tientallen-gemeenten-overwegengenderneutraal-beleid.html (last accessed: 1-3-2018).

Mills, Anne (1986): The acquisition of gender. A study of English and German. (= Springer Series in Language and Communication 20). Berlin: Springer.

Misersky, Julia (2017): The effects of grammatical gender on reference processing in German: An ERP Study. In: Proceedings of the Master's Programme Cognitive Neuroscience of the Radboud University 12, 1. 74-82. www.ru.nl/publish/pages/825831/julia_misersky_ printversion.pdf (last accessed: 8-7-2019).

Pavlenko, Aneta (2014): The bilingual mind and what it tells us about language and thought. Cambridge: Cambridge University Press.

Pavlenko, Aneta/Blackledge, Adrian/Piller, Ingrid/Teutsch-Dwyer, Marya (eds.) (2001): Multilingualism, second language learning and gender. (= Language, Power and Social Process 6). Berlin/New York: De Gruyter Mouton.

Peters, Lisa (2016): Geen man of vrouw? Dan ben je voortaan een 'hen'. In: De Correspondent, 16 Juni 2016. https://decorrespondent.nl/4748/geen-man-of-vrouw-dan-ben-je-voortaaneen-hen/1050864703020-d399a42e (last accessed: 8-7-2019)

Romein-Verschoor, Annie (1975): Over taal en seks, seksisme en emancipatie. In: De Gids 138. 3-36. [Also published 1995 in: Verbiest, Agnes/van de Zande, Anne (eds.): Een zee van golven. 5 jaar Annie Romein-Verschoor. Nijmegen: VITA.]

Sabourin, Laura/Stowe, Laurie/de Haan, Ger (2006): Transfer effects in learning a second language grammatical gender system. In: Second Language Research 22, 1. 1-29.

Sabourin, Laura/Stowe, Laurie (2008): Second language processing: When are first and second languages processed similarly? In: Second Language Research 24, 3. 397-430. 
Salamoura, Angeliki/Williams, John (2007): The representation of grammatical gender in the bilingual lexicon: Evidence from Greek and German. In: Bilingualism: Language and Cognition 10, 3. 257-275.

Sato, Sayaka/Gabriel, Ute/Gygax, Pascal (2016): Altering male-dominant representations: A study on nominalized adjectives and participles in first and second language German. In: Journal of Language and Psychology 35, 6. 667-685.

Sato, Sayaka/Gygax, Pasal/Gabriel, Ute (2016): Gauging the impact of gender grammaticization in different languages: Application of a linguistic-visual paradigm. In: Frontiers in Psychology 7. 1-13.

Schiller, Niels/Caramazza, Alfonso (2003): Grammatical feature selection in noun phrase production: Evidence from German and Dutch. In: Journal of Memory and Language 48, 1. 169-194.

Semplicini, Chiara (2012): Dutch double gender nouns: Arbitrary or motivated agreement? In: Journal of Germanic Linguistics 24, 2. 133-186.

Seton, Bregtje (2011): De appel valt niet ver van het boom: On native and non-native processing of grammatical gender violations: An ERP study. Unpublished MA-thesis. Groningen: University of Groningen (RUG).

Stahlberg, Dagmar/Sczesny, Sabine/Braun, Friederieke (2001): Name your favourite musician: Effects of masculine generics and their alternatives in German. In: Journal of Language and Social Psychology 20, 4. 464-469.

Szagun, Gisela/Stumper, Barbara/Sondag, Nina/Franik, Melanie (2007): The acquisition of gender marking by young German-speaking children: Evidence for learning guided by phonological regularities. In: Journal of Child Language 34, 3. 445-471.

Szcesny, Sabine/Formanowicz, Magda/Moser, Franziska (2016): Can gender-fair language reduce gender stereotyping and discrimination? In: Frontiers in Psychology 7. 1-11.

UNESCO (1999): Guidelines on gender-neutral language. 3rd edition. Paris: UNESCO.

UNESCO (2017): Making textbook content inclusive: A focus on religion, gender, and culture. Paris: UNESCO.

Unsworth, Sharon (2008): Age and input in the acquisition of grammatical gender in Dutch. In: Second Language Research 24, 3. 365-395.

Unsworth, Sharon/Hulk, Aafke (2010a): L1 acquisition of neuter gender in Dutch: Production and judgement. In: Proceedings of Generative Approaches to Language Acquisition 2009. 50-51.

Unsworth, Sharon/Hulk, Aafke (2010b): L1 acquisition of neuter gender in Dutch: Production and judgement. In: Costa, Joâo/Castro, Ana/Lobo, Maria/Pratas, Fernanda (eds.): Language acquisition and development. Proceedings of GALA 2009. Cambridge: Cambridge Scholars Publishing. 483-492.

Urbanek, Lukas/Poarch, Greg/Schimke, Sarah/Fanta, Johanna/De Vogelaer, Gunther (2017): Anders, of toch niet? Het Nederlandse pronominale genus door de bril van Duitse NVT-leerders. In: Dutch Journal of Applied Linguistics 6, 2. 147-173.

Van Alphen, Ingrid (1983): Een vrouw een vrouw, een woord een woord. Over de gelijke behandeling van vrouwen en mannen en de consequenties daarvan voor beroepsbenamingen in het Nederlands. In: Tijdschrift voor Vrouwenstudies 14. 306-315.

Van Berkum, Jos (1996): The psycholinguistics of grammatical gender: Studies in language comprehension and production. Doctoral dissertation, Max Planck Institute for Psycholinguistics. Nijmegen: Nijmegen University Press.

Van der Velde, Marlies (2004): L'acquisition des articles définis en L1: Étude comparative entre le francais et le Néerlandais. In: Acquisition et Interaction en Langue Étrangère 21. 9-46. 
Van Emmerik, Joanne/van Hout, Roeland/van de Craats, Inete/Klatter-Folmer, Jetske (2009): "Het" gaat niet vanzelf. De verwerving van het genus door dove volwassenen en horende tweedetaalleerders. In: Taal en Tongval 61, 1. 188-226.

Vanhove, Jan (2017): The influence of standard and substandard Dutch on gender assignment in second language German. In: Language Learning 67, 2. 431-460.

Vermeulen, Margreet (2018): “Herr Professorin” of: Hoe maak je taal echt sekseneutraal? In: De Volkskrant: Sir Edmund 29. 42-44.

Vervecken, Dries/Hannover, Bettina/Wolter, Ilka (2013): Changing (s)expectations: How gender fair job descriptions impact children's perceptions and interest regarding traditionally male occupations. In: Journal of Vocational Behaviour 82, 3. 208-220.

Weber, Andrea/Paris, Garance (2004): The origin of the linguistic gender effect in spoken-word recognition: Evidence from non-native listening. In: Forbus, Kenneth/Gentner, Dedre/Regier, Terry (eds.): Proceedings of the 26th Annual Meeting of the Cognitive Science Society. Mahwah, NJ: Erlbaum.

Werkgroep = Werkgroep Wijziging Beroepsbenaming (1982): Gevraagd. Aanzet tot een discussie over het wijzigen van den beroepsbenaming in het kader van de wet gelijke behandeling mannen en vrouwen. Amsterdam: Uitgave Ministerie van Sociale Zaken en Werkgelegenheid en de aktiegroep Man Vrouw Maatschappij. 